\title{
ISOQUINOLINE-BASED AMINO ACID DERIVATIVES
}

\author{
Gary M. Coppola*, Y. Larry Zhang and Herbert F. Schuster \\ Department of Metabolic and Cardiovascular Diseases \\ Novartis Pharmaceuticals \\ 556 Morris Ave., Summit, N.J. 07901
}

\begin{abstract}
A series of 1-aminoalkylisoquinoline-4-carboxylates (9) was synthesized by acylation of an appropriate phenethylamine derivative (4) with a phthaloyl-protected amino acid (5) followed by a Bischler-Napieralski cyclization and oxidation. N-Alkyl analogs 16 were prepared by reaction of the 1-chloromethylisoquinoline 12 with an alkylamine.
\end{abstract}

\section{Introduction}

The isoquinoline nucleus can be found in a wide variety of naturally occurring alkaloids as well as being used as biologically active agents $(1,2)$. Recently, we required a series of isoquinolines functionalized with an aminoalkyl group at the 1-position and a carboxylate at the 4-position (1). Isoquinolines with a 4 -carboxy function $(3,4,5)$ or a 1 -aminomethyl group $(6,7,8)$ are separately known but it appears that isoquinolines containing both functionalities in the same molecule are unknown.<smiles>[R]OC(=O)c1cnc(C)c2ccc([X])cc12</smiles>

1

Synthetically, 1-aminomethylisoquinolines can be accessed by catalytic reduction of the corresponding 1-cyano derivative $(6,7)$, however, this method would not be suitable for the introduction of 1-aminoalkyl groups with longer carbon chains. After careful consideration of the generality of the synthetic route, we chose a classical Bischler-Napieralski cyclization (9) to form the 
isoquinoline core. The resulting 3,4-dihydroisoquinoline could then be aromatized to the desired heterocycle.

\section{Results and Discussion}

The starting phenethylamine derivative (4) with the requisite ester in the appropriate location was conveniently prepared by deprotonation of phenylacetonitrile 2 with two equivalents of LDA followed by alkylation with ethyl chloroformate. Catalytic hydrogenation of 3 in the presence of $\mathrm{HCl}$ furnished 4 in $55-100 \%$ overall yields. Coupling of 4 with phthaloyl-protected amino acid 5 afforded amide 6 in high yields (see Table 1).

\section{Scheme 1}

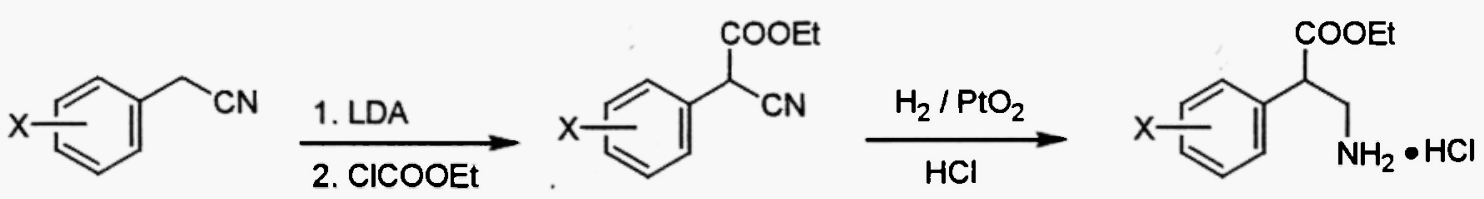

2<smiles>CC(=O)CN1C(=O)c2ccccc2C1=O</smiles>

5
3<smiles>[X]c1ccc(C(CNC(=O)CNNCCCO)C(=O)OCC)cc1</smiles>

4

6<smiles>[X]c1ccc2c(c1)C(C)=NCC2C(=O)OCC</smiles><smiles>COCCCCO</smiles><smiles>[X]c1ccc2c(C(=O)OCC)cnc(C)c2c1</smiles>

$\mathrm{N}_{2} \mathrm{H}_{4}$<smiles>[X]c1ccc2c(CN)ncc(C(=O)OCC)c2c1</smiles>

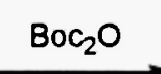<smiles>[X]c1ccc2c(CNC(=O)OCc3ccccc3)c(C)cnc2c1C(=O)OCC</smiles> 
Compounds 6 were cyclized with phosphorus oxychloride under standard BischlerNapieralski conditions to give the 3,4-dihydroisoquinoline 7. This material typically was directly aromatized in the following step, however $7 \mathbf{b}, \mathbf{7 d}$ and $7 \mathbf{j}$ were purified by crystallization and characterized. Dehydrogenation of 7 with $\mathrm{MnO}_{2}$ produced the key isoquinoline 8 in moderate overall yield from 6 (Scheme 1).

Table 1. Percent Yields of Chemical Transformations Shown in Scheme 1<smiles>[R]COC(=O)c1cnc(C)c2c([R])c([R3])c([R])c([R])c12</smiles>

\begin{tabular}{|c|c|c|c|c|c|c|c|c|}
\hline Cmpd. & $R_{1}$ & $\mathrm{R}_{\mathbf{2}}$ & $\mathbf{R}_{\mathbf{3}}$ & $\mathrm{R}_{4}$ & $n$ & $6^{a}$ & $8^{a b}$ & $10^{a b}$ \\
\hline $\mathbf{a}$ & $\mathrm{H}$ & $\mathrm{OCH}_{3}$ & $\mathrm{H}$ & $\mathrm{H}$ & 1 & 97 & 35 & 32 \\
\hline b & $\mathrm{H}$ & $\mathrm{OCH}_{3}$ & $\mathrm{OCH}_{3}$ & $\mathrm{H}$ & 1 & 90 & 46 & 81 \\
\hline c & $\mathrm{H}$ & $\mathrm{OCH}_{3}$ & $\mathrm{OCH}_{3}$ & $\mathrm{H}$ & 2 & 77 & 76 & 22 \\
\hline d & $\mathrm{H}$ & $\mathrm{OCH}_{3}$ & OEt & $\mathrm{H}$ & 1 & 84 & 34 & 78 \\
\hline e & $\mathrm{H}$ & OEt & $\mathrm{OCH}_{3}$ & $\mathrm{H}$ & 1 & 97 & 39 & 62 \\
\hline f & $\mathrm{H}$ & $\mathrm{OCH}_{3}$ & OPr & $\mathrm{H}$ & 1 & 88 & 49 & 48 \\
\hline $\mathbf{g}$ & $\mathrm{H}$ & $\mathrm{OCH}_{3}$ & $\mathrm{OH}$ & $\mathrm{H}$ & 1 & 87 & - & - \\
\hline$h$ & $\mathrm{H}$ & $\mathrm{OCH}_{3}$ & OTBS & $\mathrm{H}$ & 1 & (c) & 66 & 68 \\
\hline $\mathbf{i}$ & $\mathrm{H}$ & $\mathrm{OCH}_{3}$ & $\mathrm{H}$ & $\mathrm{OCH}_{3}$ & 1 & 89 & 61 & 21 \\
\hline $\mathbf{j}$ & $\mathrm{OCH}_{3}$ & $\mathrm{H}$ & $\mathrm{H}$ & $\mathrm{OCH}_{3}$ & 1 & 62 & $26^{d}$ & 49 \\
\hline k & $\mathrm{OCH}_{3}$ & $\mathrm{OCH}_{3}$ & $\mathrm{OCH}_{3}$ & $\mathrm{H}$ & 1 & 85 & 20 & 80 \\
\hline 1 & $\mathrm{H}$ & $\mathrm{OCH}_{3}$ & $\mathrm{OCH}_{3}$ & $\mathrm{OCH}_{3}$ & 1 & 80 & 63 & 78 \\
\hline
\end{tabular}

(a) For melting points see reference 10

(b) Overall yield of two steps

(c) $7 \mathrm{~g}$ was converted to $7 \mathrm{~h}$ before aromatization to $\mathbf{8 h}$

(d) Based on consumed starting material

Hydrazinolysis of the phthaloyl group under standard conditions ( 5 equiv. $\mathrm{N}_{2} \mathrm{H}_{4}, \mathrm{EtOH}$ ) produced erratic results especially on larger scales $(>200 \mathrm{mg}$ ). We have found that using 15 equivalents of hydrazine in $\mathrm{CH}_{2} \mathrm{Cl}_{2} / \mathrm{EtOH}(9: 1)$ gave consistent results regardless of the scale of the reaction. In order to facilitate purification of the amine 9 it was converted to its Boc derivative 10 and then flash chromatographed. The Boc protecting group was then removed with either anhydrous 
$\mathrm{HCl}$ in ethanol $\left(0^{\circ} \mathrm{C}, 5 \mathrm{~min}\right)$ or trifluoroacetic acid in methylene chloride (room temperature, $4 \mathrm{hr}$ ) to furnish pure 9 as its $\mathrm{di}-\mathrm{HCl}$ or di-TFA salt.

$\mathrm{N}$-Alkyl analogs were prepared by displacement of the halogen of the chloromethylisoquinoline 12 with various amines (Scheme 2). Compound 12 was synthesized in 11\% yield by a Bischler-Napieralski cyclization of 11 followed by aromatization with $\mathrm{MnO}_{2}$. Alternatively, 12 can be accessed by chlorination of the 1-methylisoquinoline 14 with NCS/AIBN. Under these reaction conditions both mono- and dichloro derivatives were formed. They were separable by flash chromatography and provided 12 in 23\% yield and 15 in 36\% yield. The 1-chloromethylisoquinoline 12 was then reacted with methylamine, dimethylamine and n-propylamine to give $16 a\left(R_{1}=H, R_{2}=\right.$ $\left.\mathrm{CH}_{3}\right)$, 16b $\left(\mathrm{R}_{1}=\mathrm{R}_{2}=\mathrm{CH}_{3}\right)$ and $16 \mathrm{c}\left(\mathrm{R}_{1}=\mathrm{H}, \mathrm{R}_{2}=n-\mathrm{Pr}\right)$. In the cases of 16a and 16c, they were converted to their N-Boc derivatives $17\left(R_{1}=B o c\right)$ for purification and analytical purposes. The Boc group was then removed with anhydrous $\mathrm{HCl}$ to regenerate the pure amine 16

\section{Scheme 2}<smiles>CCOC(=O)C(CNC(=O)CCl)c1ccc(OC)c(OC)c1</smiles>

11

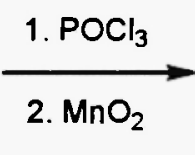<smiles>CCOC(=O)c1cnc(CCl)c2cc(OC)c(OC)cc12</smiles>

12<smiles>CCCCCCCS</smiles><smiles>CCOC(=O)C(CNC(C)=O)c1ccc(OC)c(OC)c1</smiles>

13
1. $\mathrm{POCl}_{3}$

2. $\mathrm{MnO}_{2}$<smiles>CCOC(=O)c1cnc(C)c2cc(OC)c(OC)cc12</smiles>

14<smiles>[R]NCc1ncc(C(=O)OCC)c2cc(OC)c(OC)cc12</smiles><smiles>CCOC(=O)c1cnc(CCl)c2cc(OC)c(OC)cc12</smiles>

15

\section{Experimental}

\section{General Procedure for the Preparation of 3}

To a solution of $10.1 \mathrm{~g}$ (100 mmole) of diisopropylamine in $120 \mathrm{ml}$ of THF at $-30^{\circ} \mathrm{C}$ was added 6.4 $\mathrm{g}$ (100 mmole) of $n$-butyllithium ( $1.6 \mathrm{M}$ in hexane). The mixture was cooled to $-78^{\circ} \mathrm{C}$ then a solution of 50 mmole of 2 in $80 \mathrm{ml}$ of THF was added dropwise. After stirring the mixture for 15 min a solution of $51 \mathrm{mmole}$ of ClCOOEt in $10 \mathrm{ml}$ of THF was added dropwise at which point a thick gum 
formed. The mixture was stirred at $-78^{\circ} \mathrm{C}$ for 15 min then saturated $\mathrm{NH}_{4} \mathrm{Cl}$ was added. The organic material was extracted into MTBE and the solution was dried over sodium sulfate. The solvent was removed under reduced pressure to furnish the product 3 (12).

\section{General Procedure for the Preparation of 4}

A solution of 44 mmole of 3 and $3.8 \mathrm{ml}$ of concentrated $\mathrm{HCl}$ in $150 \mathrm{ml}$ of ethanol was hydrogenated at $50 \mathrm{psi}$ over $1.1 \mathrm{~g}$ of platinum oxide for $24 \mathrm{hr}$. The catalyst was removed by filtration and the solvent evaporated under reduced pressure to give 4 (12).

\section{General Procedure for the Preparation of 6}

To a mixture of 3.45 mmole of 4, 3.5 mmole of 5, 3.45 mmole of EDC and 3.45 mmole of HOAt in $20 \mathrm{ml}$ of DMF was added $3.5 \mathrm{mmole}$ of triethylamine. The yellow mixture was stirred at room temperature for $18 \mathrm{hr}$ at which point the solution became light straw-colored. The DMF was removed under vacuum and ethyl acetate was added to the residue. The mixture was washed with $10 \% \mathrm{NaHCO}_{3}$, water and saturated $\mathrm{NaCl}$. The organic phase was dried over sodium sulfate and the solvent removed under reduced pressure to furnish 6 . The material was recrystallized from methylene chloride/MTBE (12).

\section{General Procedure for the Preparation of 8}

To a solution of $28.6 \mathrm{mmole}$ of 6 in $200 \mathrm{ml}$ of acetonitrile was added dropwise $9.5 \mathrm{~g}$ of $\mathrm{POCl}_{3}$ and the resulting mixture was stirred at $80-85^{\circ} \mathrm{C}$ for $48 \mathrm{hr}$. The solvent was removed under reduced pressure and $2 \mathrm{~N} \mathrm{NaOH}$ was added to the residue. The mixture was extracted with ethyl acetate, the organic phase was dried over sodium sulfate and the solvent was removed under reduced pressure to give 7. This material was dissolved in $200 \mathrm{ml}$ of benzene and $30 \mathrm{~g}$ of activated $\mathrm{MnO}_{2}$ was added. The mixture was refluxed for $1 \mathrm{hr}$ in a flask fitted with a Dean-Stark trap. After filtering the $\mathrm{MnO}_{2}$ through Celite, the solvent was removed under reduced pressure to give 8 . The material was recrystallized from methylene chloride/ethyl acetate (12).

\section{General Procedure for the Hydrazinolysis of 8}

To a solution of 2 mmole of 8 in $50 \mathrm{ml}$ of methylene chloride/ethanol (10:1) was added 15 equivalents of anhydrous hydrazine and the mixture was stirred at room temperature for $24 \mathrm{hr}$. The solvent was removed under reduced pressure and the solid residue was partitioned between methylene chloride and water. The organic phase was washed with water $(2 x)$ and dried over sodium sulfate. The solvent was removed under reduced pressure to give 9 


\section{General Procedure for the Preparation of 10}

To a solution of 2.5 mmole of 9 and 4 mmole of triethylamine in $20 \mathrm{ml}$ of methylene chloride was added 3 mmole of $\mathrm{Boc}_{2} \mathrm{O}$. After stirring the mixture for $2.5 \mathrm{hr}$, the solvent was removed under reduced pressure and the residual solid was flash chromatographed using methylene chloride/ethyl acetate (4:1) to elute pure 10 (12). The same procedure was used for the conversion of 16 to 17.

\section{General Procedure For Removal of the Boc Group}

Into a solution of 10 in $\mathrm{EtOH} / \mathrm{CH}_{2} \mathrm{Cl}_{2}(8: 2)$ at $0^{\circ} \mathrm{C}$ was bubbled $\mathrm{HCl}$ gas for $2-5 \mathrm{~min}$. The solution was concentrated and ether was added. The resulting precipitate was filtered and washed with ether to afford pure 9 as its dihydrochloride salt. The same procedure was used for the conversion of 17 to 16.

\section{Ethyl 6,7-Dimethoxy-1-methylisoquinoline-4-carboxylate (14)}

The acetyl derivative 13 , which was prepared by treating $\mathbf{4 b}$ with acetic anhydride in the presence of triethylamine, was converted to 14 according to the general procedure for the preparation of 8 to give $1.5 \mathrm{~g} \mathrm{(54 \% )}$ of a yellow solid, $\mathrm{mp} 141-142^{\circ} \mathrm{C} ;{ }^{1} \mathrm{H} \mathrm{nmr}\left(\mathrm{CDCl}_{3}\right): \delta 9.00(\mathrm{~s}, 1 \mathrm{H}), 8.51(\mathrm{~s}, 1 \mathrm{H})$, $7.33(\mathrm{~s}, 1 \mathrm{H}), 4.47(\mathrm{q}, 2 \mathrm{H}), 4.08(\mathrm{~s}, 3 \mathrm{H}), 4.05(\mathrm{~s}, 3 \mathrm{H}), 2.95(\mathrm{~s}, 3 \mathrm{H}), 1.46(\mathrm{t}, 3 \mathrm{H})$. Anal. Calcd. for $\mathrm{C}_{15}$ $\mathrm{H}_{17} \mathrm{NO}_{4}: \mathrm{C}, 65.44 ; \mathrm{H}, 6.22 ; \mathrm{N}, 5.09$. Found: $\mathrm{C}, 65.25 ; \mathrm{H}, 6.22 ; \mathrm{N}, 5.03$.

\section{Chlorination of 14}

A mixture of $3.5 \mathrm{~g}$ (12.7 mmole) of $14,2.2 \mathrm{~g}$ (16.5 mmole) of $\mathrm{N}$-chlorosuccinimide and $0.4 \mathrm{~g}$ of AIBN in $100 \mathrm{ml}$ of $\mathrm{CCl}_{4}$ was refluxed for $18 \mathrm{hr}$. TLC showed some unreacted 14 remaining so an additional $0.6 \mathrm{~g}$ of $\mathrm{N}$-chlorosuccinimide and $0.1 \mathrm{~g}$ of AIBN was added and refluxing was continued for an additional $10 \mathrm{hr}$. The solvent was removed under reduced pressure and the residue flash chromatographed using methylene chloride/ethyl acetate (100:1) to elute the products, $1.6 \mathrm{~g} \mathrm{(36 \% )}$ of 15 , mp $108-110^{\circ} \mathrm{C},{ }^{1} \mathrm{H} \mathrm{nmr}\left(\mathrm{CDCl}_{3}\right): \delta 8.98(\mathrm{~s}, 1 \mathrm{H}), 8.50(\mathrm{~s}, 1 \mathrm{H}), 8.00(\mathrm{~s}, 1 \mathrm{H}), 7.22(\mathrm{~s}, 1 \mathrm{H}), 4.48$ $(q, 2 \mathrm{H}), 4.09(\mathrm{~s}, 6 \mathrm{H}), 1.46(\mathrm{t}, 3 \mathrm{H})$. Anal. Calcd. for $\mathrm{C}_{15} \mathrm{H}_{15} \mathrm{NO}_{4} \mathrm{Cl}_{2}: \mathrm{C}, 52.34 ; \mathrm{H}, 4.39 ; \mathrm{N}, 4.07 ; \mathrm{Cl}$, 20.60. Found: $\mathrm{C}, 52.21 ; \mathrm{H}, 4.20 ; \mathrm{N}, 3.95 ; \mathrm{Cl}, 20.96$.

Also $0.7 \mathrm{~g}(23 \%)$ of $12, \mathrm{mp} 172-173^{\circ} \mathrm{C},{ }^{1} \mathrm{H} \mathrm{nmr}\left(\mathrm{CDCl}_{3}\right): \delta 9.02(\mathrm{~s}, 1 \mathrm{H}), 8.50(\mathrm{~s}, 1 \mathrm{H}), 7.46(\mathrm{~s}, 1 \mathrm{H})$, $5.09(\mathrm{~s}, 2 \mathrm{H}), 4.47(\mathrm{q}, 2 \mathrm{H}), 4.08(\mathrm{~s}, 6 \mathrm{H}), 1.45(\mathrm{t}, 3 \mathrm{H})$. Anal. Calcd. for $\mathrm{C}_{15} \mathrm{H}_{16} \mathrm{NO}_{4} \mathrm{Cl}: \mathrm{C}, 58.17 ; \mathrm{H}$, $5.21 ; \mathrm{N}, 4.52 ; \mathrm{Cl}, 11.45$. Found: $\mathrm{C}, 58.07 ; \mathrm{H}, 5.10 ; \mathrm{N}, 4.42 ; \mathrm{Cl}, 11.74$.

\section{Reaction of 12 With Amines}

Methylamine or dimethylamine was condensed in $15 \mathrm{ml}$ of THF at $-78^{\circ} \mathrm{C}$ until a volume increase of 3-5 ml was observed. To this was added dropwise a solution of $120 \mathrm{mg}$ of $12 \mathrm{in} 15 \mathrm{ml}$ of THF. The mixture was allowed to warm to room temperature and stirred there for $2 \mathrm{hr}(11)$. The solvent was 
removed under reduced pressure and the residue partitioned between methylene chloride and water. The organic phase was dried over sodium sulfate and the solvent evaporated to give $\mathbf{1 6}$

\section{References}

(1) M. Shamma, The Isoquinoline Alkaloids, Chemistry and Pharmacology, Academic Press, New York, 1972.

(2) F. G. Kathawala, G. M. Coppola and H. F. Schuster (Eds.), Heterocyclic Compounds, Isoquinolines, Part 2, John Wiley, New York, 1990.

(3) W. Bartmann, E. Konz and W. Ruger, Heterocycles 29, 707 (1989).

(4) H. Suzuki and H. Abe, Synthesis 763 (1995).

(5) L. Wessjohann, L. Skattebol and A. de Meijere, J. Chem. Soc., Chem. Commun., 574 (1990).

(6) A. Kubo, Y. Kitahara, S. Nakahara, R. Iwata and R. Numata, Chem. Pharm. Bull. 36, 4355 (1988).

(7) K. Matsuo, M. Okumura and K. Tanaka, Chem. Pharm. Bull. 30, 4170 (1982).

(8) M. Croisy-Delcey, C. Huel and E. Bisagni, J. Heterocyclic Chem. 25, 655 (1988).

(9) W. M. Whaley and T. R. Govindachari, Organic Reactions, Vol. 6, John Wiley, New York, 1951 .

(10) Melting points of crystalline products: $3 \mathrm{e}, 59-61^{\circ} ; \mathbf{4 b}, 171-174^{\circ} ; \mathbf{4 d}, 119-122^{\circ} ; 4 \mathbf{e}, 134-135^{\circ}$; 4f, $102-105^{\circ} ; \mathbf{4 g}, 159-162^{\circ} ; 4 \mathrm{i}, 165-167^{\circ} ; 41,135-135^{\circ} ; 6 \mathrm{~b}, 151-153^{\circ} ; 6 \mathrm{c}, 140-143^{\circ} ; 6 \mathrm{~d}, 145-$ $148^{\circ} ; 6 \mathrm{e}, 149-151^{\circ} ; 6 \mathrm{f}, 132-135^{\circ} ; 6 \mathrm{i}, 151-153^{\circ} ; 6 \mathrm{j}, 111-115^{\circ} ; 6 \mathrm{k}, 45-47^{\circ}, 61,182-184^{\circ} ; 7 \mathrm{~b}$,

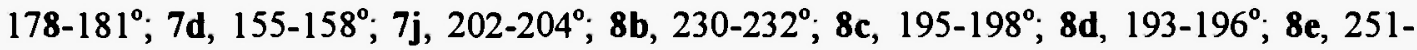

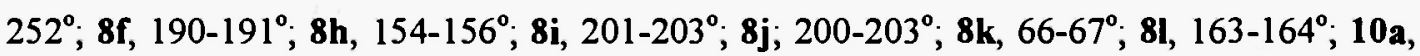

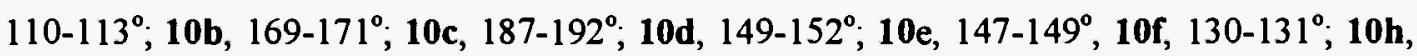
$130-131^{\circ} ; 10 \mathrm{i}, 163-164^{\circ} ; 10 \mathrm{j}, 141-144^{\circ} ; 10 \mathrm{k}, 154-155^{\circ} ; 101,118-120^{\circ} ; 17 \mathrm{a}, 98-100^{\circ} ; 17 \mathrm{c}$, $110-112^{\circ}$; The following are di-HCl salts: $9 \mathrm{a}, 177-179^{\circ}$ [dec]; 9b, 225-228 ${ }^{\circ}$ [dec]; 9d, $260-$

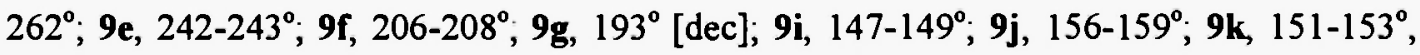

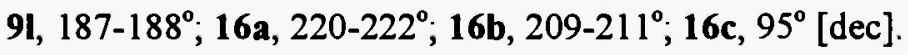

(11) In the case of $16 \mathrm{c}, 5 \mathrm{ml}$ of $n$-propylamine was used and the reaction stirred at room temperature $21 \mathrm{hr}$.

(12) Representative ${ }^{1} \mathrm{H}$ nmr spectra: $3 \mathrm{~b}\left(\mathrm{CDCl}_{3}\right): \delta$ 7.02-6. $82(\mathrm{~m}, 3 \mathrm{H}), 4.65(\mathrm{~s}, 1 \mathrm{H}), 4.25(\mathrm{q}, 2 \mathrm{H})$, $3.92(\mathrm{~s}, 3 \mathrm{H}), 3.90(\mathrm{~s}, 3 \mathrm{H}), 1.29(\mathrm{t}, 3 \mathrm{H}) .4 \mathrm{~b}(\mathrm{DMSO}): \delta 8.29(\mathrm{~s}$, broad, $3 \mathrm{H}), 6.98-6.77(\mathrm{~m}$, $3 \mathrm{H}), 4.10(\mathrm{~m}, 3 \mathrm{H}), 3.78(\mathrm{~s}, 3 \mathrm{H}), 3.77(\mathrm{~s}, 3 \mathrm{H}), 3.40(\mathrm{~m}, 1 \mathrm{H}), 3.03(\mathrm{~m}, 1 \mathrm{H}), 1.15(\mathrm{t}, 3 \mathrm{H}) .6 \mathbf{b}$ $\left(\mathrm{CDCl}_{3}\right): \delta 7.88(\mathrm{~m}, 1 \mathrm{H}), 7.75(\mathrm{~m}, 1 \mathrm{H}), 6.77(\mathrm{~s}, 3 \mathrm{H}), 6.25(\mathrm{t}$, broad, $1 \mathrm{H}), 4.30(\mathrm{~s}, 2 \mathrm{H}), 4.16$, $(\mathrm{m}, 2 \mathrm{H}), 3.87(\mathrm{~s}, 3 \mathrm{H}),(3.83, \mathrm{~s} 3 \mathrm{H}), 3.82(\mathrm{~m}, 1 \mathrm{H}), 3.68(\mathrm{t}, 2 \mathrm{H}), 1.22(\mathrm{t}, 3 \mathrm{H}) .7 \mathrm{~b}\left(\mathrm{CDCl}_{3}\right): \delta$ $7.87(\mathrm{~m}, 2 \mathrm{H}), 7.70(\mathrm{~m}, 2 \mathrm{H}), 7.10(\mathrm{~s}, 1 \mathrm{H}), 6.81(\mathrm{~s}, 1 \mathrm{H}), 4.89(\mathrm{~s}, 2 \mathrm{H}), 4.17(\mathrm{q}, 2 \mathrm{H}), 4.08(\mathrm{~m}$, $1 \mathrm{H}), 3.96(\mathrm{~s}, 3 \mathrm{H}), 3.92(\mathrm{~s}, 3 \mathrm{H}), 3.72(\mathrm{~m}, \mathrm{HH}), 3.60(\mathrm{t}, 1 \mathrm{H}), 1.23(\mathrm{t}, 3 \mathrm{H}) .8 \mathbf{b}\left(\mathrm{CDCl}_{3}\right): \delta 8.97$ $(\mathrm{s}, 1 \mathrm{H}), 8.52(\mathrm{~s}, 1 \mathrm{H}), 7.93(\mathrm{~m}, 2 \mathrm{H}), 7.77(\mathrm{~m}, 2 \mathrm{H}), 7.46(\mathrm{~s}, 1 \mathrm{H}), 5.48(\mathrm{~s}, 2 \mathrm{H}), 4.41(\mathrm{q}, 2 \mathrm{H})$, 
$4.07(\mathrm{~s}, 6 \mathrm{H}), 1.41(\mathrm{t}, 3 \mathrm{H}) .9 \mathrm{~b}$ (di-HCl salt) $\left(\mathrm{D}_{2} \mathrm{O}\right): \delta 8.85(\mathrm{~s}, 1 \mathrm{H}), 7.64(\mathrm{~s}, 1 \mathrm{H}), 7.07(\mathrm{~s}, 1 \mathrm{H})$, $4.77(\mathrm{~s}, 2 \mathrm{H}), 4.43(\mathrm{q}, 2 \mathrm{H}), 3.99(\mathrm{~s}, 3 \mathrm{H}), 3.78(\mathrm{~s}, 3 \mathrm{H}), 1.50(\mathrm{t}, 3 \mathrm{H}), 10 \mathrm{~b}\left(\mathrm{CDCl}_{3}\right): \delta 9.02(\mathrm{~s}$, $1 \mathrm{H}), 8.50(\mathrm{~s}, 1 \mathrm{H}), 7.37(\mathrm{~s}, 1 \mathrm{H}), 6.25(\mathrm{~s}$, broad, $1 \mathrm{H}), 4.93(\mathrm{~d}, 2 \mathrm{H}), 4.46(\mathrm{q}, 2 \mathrm{H}), 4.08(\mathrm{~s}, 3 \mathrm{H})$, $4.02(\mathrm{~s}, 3 \mathrm{H}), 1.59-1.45(\mathrm{~m}, 12 \mathrm{H})$.

Received on December 11, 1999 